\title{
Assessment of biological colonization of historic buildings in the former Auschwitz II-Birkenau concentration camp
}

\author{
Katarzyna Rajkowska • Anna Otlewska • Anna Koziróg • \\ Małgorzata Piotrowska • Paulina Nowicka-Krawczyk • \\ Mariusz Hachulka • Grzegorz J. Wolski • \\ Alina Kunicka-Styczyńska • Beata Gutarowska • \\ Agnieszka Żydzik-Białek
}

Received: 13 May 2013 / Accepted: 1 August 2013 / Published online: 15 August 2013

(C) The Author(s) 2013. This article is published with open access at Springerlink.com

\begin{abstract}
The objective of this study was to assess biological colonization of wooden and brick buildings in the former Auschwitz II-Birkenau concentration camp, and to identify the organisms colonizing the examined buildings. Microbiological analysis did not reveal increased microbial activity, and the total microbial count of the barrack surfaces did not exceed $10^{3} \mathrm{CFU} / 100 \mathrm{~cm}^{2}$. However, certain symptoms of biodegradation of the buildings were observed. The predominant microflora consisted of bacteria of the genera Bacillus, Sporosarcina, Pseudomonas, Micrococcus, Streptomyces, and Staphylococcus, as well as fungi of the genera Acremonium, Cladosporium, Alternaria, Humicola, Penicillium, and Chaetomium. The microflora patterns varied both in wooden and brick buildings. The structural elements of wooden and brick barracks, and especially of the floors and lower parts of bathroom walls, were infected by cyanobacteria and algae, with the most numerous being cyanobacteria of the genera Scytonema, Chroococcus, Gloeothece, Leptolyngbya,
\end{abstract}

K. Rajkowska $(\bowtie) \cdot$ A. Otlewska $\cdot$ A. Koziróg $\cdot$ M. Piotrowska $\cdot$

A. Kunicka-Styczyńska $\cdot$ B. Gutarowska

Institute of Fermentation Technology and Microbiology,

Lodz University of Technology, Wólczańska St. 171/173,

90-924 Lodz, Poland

e-mail: katarzyna.rajkowska@p.lodz.pl

P. Nowicka-Krawczyk • M. Hachułka

Department of Algology and Mycology, University of Lodz,

Banacha St. 12/16, 90-237 Lodz, Poland

G. J. Wolski

Department of Geobotany and Plant Ecology, University of Lodz, Banacha St. 12/16, 90-237 Lodz, Poland

A. Żydzik-Białek

Auschwitz-Birkenau State Museum, Więźniów Oświęcimia St. 20,

32-603 Oświęcim, Poland diatoms of the genus Diadesmis, and chlorophytes of the genera Chlorella and Apatococcus. The outer surfaces of the examined buildings were primarily colonized by lichens and bryophytes, with nearly 30 species identified. The dominant species of lichens belonged to the genera Candelariella, Caloplaca, Lecanora, Lecidea, Lepraria, Physcia, and Protoparmeliopsis, and those of bryophytes to the genera Bryum, Ceratodon, Marchantia, and Tortula. The quantity and species diversity of lichens and mosses were much lower in wooden barracks than in brick ones. The external surfaces of those barracks were only affected by Lecanora conizaeoides, Lecanora symmicta, Lepraria cf. incana, and Strangospora pinicola. The study results revealed vast biodiversity among the species colonizing historic buildings. The presence of these groups of organisms, resulting from their natural expansion in the environment, is undesirable, as their excessive growth and spread may lead to progressive biodegradation of buildings. Our assessment of biological contamination will enable the development of a disinfection and conservation plan for the examined buildings.

Keywords Biodiversity $\cdot$ Biodeterioration $\cdot$ Historic buildings $\cdot$ Cultural heritage

\section{Introduction}

The Auschwitz-Birkenau Memorial Site is a genocide museum and a symbol of the Holocaust and the atrocities of World War II. The Auschwitz-Birkenau State Museum in Oświęcim spans an area of approximately 191 ha, out of which about 20 ha is occupied by the former Auschwitz I concentration camp, and about 171 ha by Auschwitz II-Birkenau. The Museum is responsible for the conservation of, among others, 155 buildings, 
about 300 relics, 35 watchtowers, four ruined gas chambers and crematories, two water treatment plants, several fire protection pools, shelters, many kilometers of railway tracks, roads, irrigation/drainage ditches, the sewage system, as well as gates and fences with over 3000 concrete posts (Świebocka T et al. 2010). To date, 98 buildings, including 22 wooden barracks, have been preserved in the former Auschwitz II-Birkenau concentration camp. Most of them are treated as historic buildings to be preserved in accordance with the principle of conserving all elements of the former concentration camp, and especially maintaining the status quo. Due to the lack of heating, active moisture insulation, or effective ventilation, as well as adverse climate conditions (changes in temperature and humidity, permanent exposure to sunlight), many of these buildings are at risk of biodeterioration caused by bacteria, cyanobacteria, fungi, algae, bryophytes, and lichens. An assessment of microbiological colonization of these buildings and an evaluation of the factors conducive to biodeterioration can be used for the development of a comprehensive strategy for long-term conservation and protection of the concentration camp buildings.

The mechanism of biodeterioration is often determined by the type of substrate on which the microorganisms are growing, the availability of nutrients, and, in the case of mineral materials, the mineralogical composition and water permeability (Cwalina and Dzierżewicz 2007). The phenomenon of biodeterioration is linked to the formation of biological films on organic and inorganic substrates. Those films consist of microbial cells and extracellular polymers. A biofilm becomes attached to the substrate by means of slime, which also facilitates absorption and retention of moisture. The presence of biofilms on construction materials leads to changes in the physical and chemical properties of the substrate, and to biodeterioration of the materials (Gaylarde and Morton 1999; Herrera et al. 2004).

Historic buildings are usually first colonized by photolithoautotrophic organisms such as algae and cyanobacteria, due to their small nutrient requirements, as all they need for growth is carbon dioxide, light, and appropriate moisture levels (Crispin and Gaylarde 2005; Herrera et al. 2004). Algal growth results in the formation of bright green or gray-green patches and streaks on construction materials. Their development causes degradation of the stone substrate due to the secretion of organic acids (lactic, oxalic, succinic, acetic, and pyruvic) (Leźnicka 1991). At the next stage of corrosion, construction materials (mostly stone, concrete, mortar, etc.) are colonized by lichens - organisms resistant to dryness and extreme temperatures. They stain the stone substrate and alter the appearance of historic buildings. Furthermore, they produce oxalic and oxaloacetic acids, which intensively deteriorate concrete and stone. Lichens and algae release considerable amounts of organic substances (carbohydrates and amino acids) to the environment, thus enabling the development of heterotrophic organisms, such as bacteria and filamentous fungi. Heterotrophs also use groundwater, absorbed into construction materials by capillary action, as a source of organic and mineral compounds. Heterotrophs can penetrate the substrate to a depth of up to $5 \mathrm{~cm}$ (Leźnicka 1991). The species that play a major role in microbiological corrosion, in indoor building materials are filamentous fungi of the genera Penicillium, Aspergillus, Cladosporium, Alternaria, Aureobasidium, Ulocladium, and Phoma, which release large amounts of citric, fumaric, oxalic, and 2ketogluconic acids (Gutarowska and Czyżowska 2009). The organic acids produced increase the solubility of some stone components, due to the formation of chelate compounds with metal cations (calcium, aluminum, silicon, iron, manganese, and magnesium) (Warscheid and Braams 2000). In the case of concrete corrosion, the salts formed may be washed out from the surface, causing increased dampness and loss of resistance to compression and crushing (Cwalina 2008). Similarly to filamentous fungi, chemoorganotrophic bacteria (Bacillus sp., Arthrobacter sp., and Streptomyces sp.) also release 2ketogluconic acid, initiating decomposition of silica (Papida et al. 2000; Warscheid and Braams 2000). Furthermore, bacteria of the genus Bacillus (B. cereus, B. subtilis and B. aquimaris) cause mineralization, resulting in the formation of calcite (calcium carbonate) or struvite (magnesium ammonium phosphate) on concrete and gypsum substrates (RodriguezNavarro et al. 2007; Zammit et al. 2011). Another major group of microorganisms that degrades historic monuments built of mineral materials consists of chemolithotrophic sulfur and nitrifying bacteria. These microorganisms use carbon dioxide as a carbon source and obtain the energy by oxidation of inorganic matter (ammonia, nitrates (III), sulfates, thiosulfates, and elemental sulfur). Nitrifying bacteria (Nitrosomonas sp. and Nitrobacter sp.) cause oxidation of ammonia and nitrates (III) to nitric (III) and (V) acids, respectively. These acids react with calcium carbonate or other minerals, resulting in readily soluble compounds. In turn, sulfur bacteria (Acidithiobacillus thiooxidans) produce sulfuric (VI) acid, which reacts with the calcium carbonate present in construction materials, forming hydrated calcium sulfate (gypsum) (Cwalina and Dzierżewicz 2007).

Filamentous and decay fungi play a significant role in the biodegradation of organic materials such as wood or woodbased products. The latter may lead to changes in the structure of wood (cubical cracking, crumbling, peeling), its chemical composition (degradation of cellulose, hemicellulose, and lignin), its physical properties (smell, color, and density), and its mechanical properties (strength). Cellulolytic moulds Chaetomium, Trichoderma, and Penicillium cause blue-green stains on the surface. Furthermore, very damp wood may be affected by bacterial growth, leading to surface biodeterioration due to decomposition of organic compounds (Ważny 2001).

The aim of the work was an assessment of biological colonization of wooden and brick buildings in the former Auschwitz II-Birkenau concentration camp, including the identification of the organisms colonizing selected buildings. 


\section{Methodology}

Four brick barracks (no. B-70, B-113, B-114 and B-124) and two wooden barracks (no. B-159 and B-169) located in the BI and BIIa sectors of the former Auschwitz II-Birkenau concentration camp were selected for examination of microbiological colonization. A detailed list of sampling sites is given in Table 1. The examinations involved microbiological (includes bacteria and fungi), phycological, lichenological and bryological analysis. Because of the fact that cyanobacteria grew in communities with other groups of algae and were not cultured on microbiological media, they were studied with traditional phycological methods.

\section{Analysis of microbiological air contamination}

Microbiological contamination of atmospheric air and air inside the barracks was measured by the impaction method using an MAS 100 Eco air sampler (Merck). The total number of bacteria was determined on TSA medium (Tryptic Soy Agar, Merck) with nystatin (0.06\%), and that of fungi on Sabouraud medium with chloramphenicol (Merck). The samples were incubated for up to 7 days. After incubation colonies were counted, and the results were expressed in units of $\mathrm{CFU} / \mathrm{m}^{3}$ (colony forming units per $1 \mathrm{~m}^{3}$ of air). All tests were done in triplicate.

Quantitative analysis of microbiological surface colonization

The microbiological colonization of inner barrack surfaces (listed in Table 1) was assessed by the count plate method and by adenosine triphosphate (ATP) measurement. Swabs were taken from areas of $25 \mathrm{~cm}^{2}$ and suspended in saline $(0.85 \% \mathrm{NaCl})$. The suspensions were plated on TSA with nystatin and on Sabouraud agar with chloramphenicol for determining total bacteria and moulds counts, respectively. The samples were incubated at room temperature $\left(25 \pm 0.5{ }^{\circ} \mathrm{C}\right)$ for up to 7 days. The results were given as $\mathrm{CFU} / 100 \mathrm{~cm}^{2}$. At the same time, ATP concentration was determined in the samples by the luminometric method using the HyLite system, Merck (Szczotko and Krogulski 2010). The results were given in relative luminescence units (RLU). All tests were done in triplicate.

Table 1 Sampling sites

\begin{tabular}{|c|c|c|c|}
\hline Type of barracks & Surface type & Material & Analyzed organisms \\
\hline \multirow[t]{13}{*}{ Brick barracks } & internal load-bearing wall & plastered brick & bacteria, moulds \\
\hline & partition wall & plastered brick & $\begin{array}{l}\text { bacteria, moulds, cyanobacteria, } \\
\text { algae }\end{array}$ \\
\hline & $\begin{array}{l}\text { bunk bed } \\
\text { door frame }\end{array}$ & $\begin{array}{l}\text { wood } \\
\text { paint-coated wood }\end{array}$ & bacteria, moulds \\
\hline & floor & wood & \\
\hline & & $\begin{array}{l}\text { brick } \\
\text { soil }\end{array}$ & cyanobacteria, algae \\
\hline & & sand and clay substrate & \\
\hline & ceiling & $\begin{array}{l}\text { cement-bonded particle } \\
\text { board }\end{array}$ & bacteria, moulds \\
\hline & strip around the building & $\begin{array}{l}\text { concrete } \\
\text { mortar }\end{array}$ & lichens \\
\hline & & stones & cyanobacteria, algae \\
\hline & external wall & concrete foundations & cyanobacteria, algae, bryophytes \\
\hline & & $\begin{array}{l}\text { mortar } \\
\text { brick }\end{array}$ & bryophytes, lichens \\
\hline & door & wood & cyanobacteria, algae, bryophytes \\
\hline & roof & roof tiles & bryophytes \\
\hline \multirow[t]{8}{*}{ Wooden barracks } & $\begin{array}{l}\text { load-bearing wall } \\
\text { partition wall }\end{array}$ & $\begin{array}{l}\text { wood } \\
\text { plastered brick }\end{array}$ & bacteria, moulds \\
\hline & beam & wood & \\
\hline & bunk bed & wood & \\
\hline & stove & brick & \\
\hline & door & wood & bryophytes, lichens \\
\hline & strip around the building & concrete & cyanobacteria, algae, bryophytes \\
\hline & & mortar & lichens \\
\hline & & stones & cyanobacteria, algae \\
\hline
\end{tabular}




\section{Identification of microorganisms}

Isolated pure cultures of bacteria and fungi were transferred to TSA and Czapek-Dox (Merck) media, respectively. The bacteria were identified by standard methods on the basis of morphological features, Gram staining, as well as biochemical assays using API tests (bioMerieux). Bacterial species were confirmed by molecular methods based on 16S rRNA gene sequencing. The obtained nucleotide sequences of the 16S rRNA gene were compared, using the BLAST 2.2.27+ software, with the sequences available from the National Center of Biotechnology Information. The identification of moulds was done based on macroscopic and microscopic morphological features in accordance to diagnostic keys (Domsch et al. 1993; Samson et al. 2000). Microbial identification was conducted for the dominant microflora strains.

\section{Phycological analysis}

Phycological samples were collected from structural elements inside and outside selected buildings (Table 1). Macroscopically varying algal biofilms and thalli were sampled and preserved in $4 \%$ formaldehyde solution. Cyanobacteria and algae were identified by the morphological features of cells, colonies, and thalli, based on Komárek and Anagnostidis (1999, 2007), Starmach (1966), Hofmann et al. (2011), Samad and Adhikary (2008), and Wołowski and Hindák (2005).

\section{Bryological analysis}

Material for bryological analysis was collected from structural elements inside and outside selected buildings (Table 1). Perishable preparations were assessed morphologically. The names of the mosses were given according to Ochyra et al. (2003), and those of liverworts pursuant to Szweykowski (2006).

\section{Lichenological analysis}

Biological material for lichenological analysis was collected from wooden and brick barracks. The fruiting bodies and thalli were examined microscopically. In identifying lichen species, we used the following keys and monographs: Nowak and Tobolewski (1975), Purvis et al. (1992), Wirth (1995a,b); for Verrucaria - Krzewicka (2012), Lepraria - Kukwa (2006), Lecanora dispersa and other Lecanora spp. - Śliwa (2007), Physcia and Phaeophyscia - Nowak (1993). The names of lichens were adopted after Santesson et al. (2004) and Diederich et al. (2010).

\section{Results and discussion}

Visual assessment of brick and wooden barracks in the $\mathrm{BI}$ and BIIa sectors of the former Auschwitz II-Birkenau concentration camp revealed deterioration of structural partitions and wooden elements of these buildings. The symptoms of deterioration visible in brick barracks include bulging and crumbling plaster, peeling paint, degradation of floor bricks, and decomposition of wood tissue in the bunk beds and floor planks (Fig. 1). In wooden barracks, the structural elements were affected by fiber splitting and cubical cracking. Locally, some biodeterioration was found in wooden elements infected by decay fungi (Fig. 1). The algae that formed colonies inside buildings usually grew on cracked concrete flooring, wooden structural elements, and on floor bricks in bathrooms. Lichens and mosses were primarily found outside buildings: on the strips surrounding the barracks, brick and mortar walls, and the roof(Fig. 2). No signs of infection with moulds or bacteria (biofilms or stains) were found on the examined building surfaces.

The absence of visual symptoms of microbial development was confirmed by analysis of surface colonization with moulds and bacteria (Table 2). The number of microorganisms on surfaces in brick barracks ranged from 8.0 to $2.7 \times$ $10^{3} \mathrm{CFU} / 100 \mathrm{~cm}^{2}$, with the major genera of bacteria Bacillus, Sporosarcina, Pseudomonas, Micrococcus, and Streptomyces and the dominant moulds Acremonium sp., Cladosporium sp., Alternaria alternata, Humicola sp., Penicillium citreonigrum, and Chaetomium globosum (Table 3). The highest degree of colonization was found on the surfaces of wooden elements (bunk beds and floors). In selected places inside the barracks, samples were taken at different heights above floor $(10,100,160$, and $210 \mathrm{~cm})$, to determine the influence of material dampness, which changes with distance from the ground, on the degree of microbiological colonization (Table 2). With increasing distance from the ground, the number of microorganisms decreased, which shows that at a height of over $100 \mathrm{~cm}$ above ground, the conditions are less favorable to active microbial development.

Similarly as in brick barracks, the total number of microorganisms in wooden barracks was low $\left(2.2 \times 10^{1}\right.$ to $8.7 \times$ $10^{2} \mathrm{CFU} / 100 \mathrm{~cm}^{2}$ ), but the species composition was different. The predominant bacteria on the barrack surfaces were Staphylococcus equorum (not present on brick barracks), Bacillus atrophaeus, Bacillus cereus, Bacillus mycoides, and Streptomyces sp., while the most widespread moulds included Aspergillus fumigatus (not present on brick barracks), Cladosporium cladosporioides, Cladosporium herbarum, Alternaria alternata, Humicola fuscoatra, and Penicillium citrinum. The microflora of wooden barracks was less diverse than that of brick buildings (Table 3).

Moulds of the genera Acremonium, Cladosporium, Penicillium, and Chaetomium have also been isolated from 
Fig. 1 Deterioration on wooden and brick-and-mortar elements. a-c wood fiber splitting; $\mathbf{c}, \mathbf{d}$ decay fungi infection; $\mathbf{e}-\mathbf{f}$ plaster crumbling and brick degradation
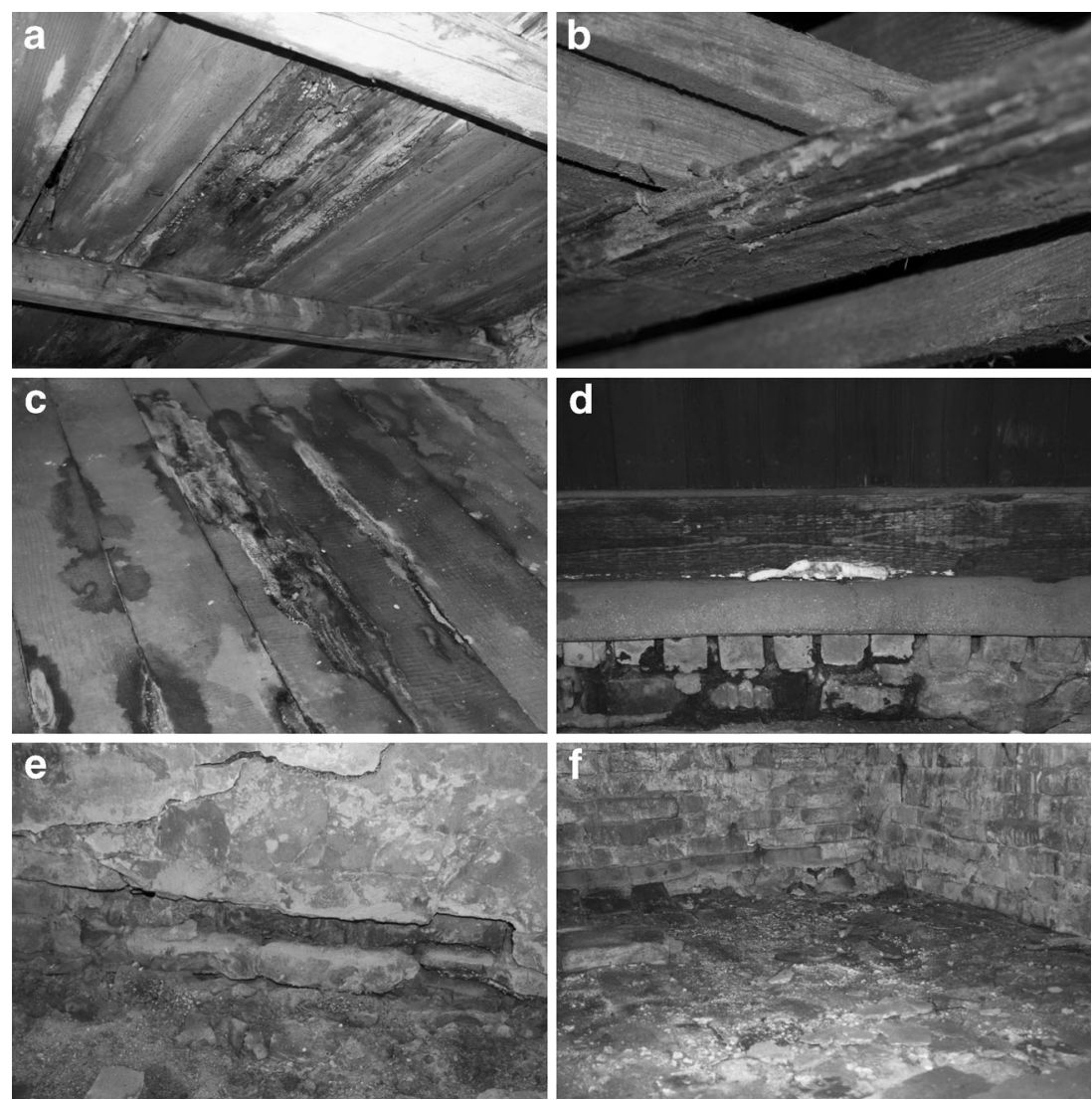

other historical wooden elements (Arenz et al. 2006; Pournou and Bogomolova 2009), as well as from brick and concrete surfaces (Cwalina 2008). Bacteria such as Achromobacter sp., Bacillus sp., Clostridium sp., Flavobacterium sp., Proteus sp., and Streptococcus sp. can colonize concrete materials, bricks, mortar, and natural stone (Cwalina 2008; Warscheid and Braams 2000) as well as wood, also that subjected to conservation (Clausen 1996).

Microorganism-induced biodeterioration of materials depends on environmental conditions such as humidity, temperature, $\mathrm{pH}$, as well as on the synergistic action of the metabolites of different microbial species and antagonism between the microorganisms (Clausen 1996; de Boer et al. 2005; Pietikäinen et al. 2005). The degree of biological colonization of bricks, concrete, and mortar is also influenced by their porosity and alkaline pH (Clausen 1996; Gaylarde et al.
2003). Additionally, historical materials may contain organic additives, including hair, glue, and sawdust, which may increase the susceptibility of mineral substrates to microbial development (Palmer et al. 1991).

Because humidity and temperature are factors that affect the development of microorganisms, these factors were monitored during research. The results showed that relative humidity varied from 40 to $56 \%$ inside wooden barracks and from 44 to $71 \%$ inside brick barracks, and the temperature ranged from 15 to $23{ }^{\circ} \mathrm{C}$ and from 14 to $22{ }^{\circ} \mathrm{C}$, respectively. In spite of the fact that the relative humidity and temperature during monitoring periods were quite favourable for the growth of microorganisms, neither the results obtained for brick barracks nor for wooden barracks indicate elevated microbial activity, in accordance with the literature (Piotrowska and Żakowska 2010). The determined microorganism levels may be deemed
Fig. 2 Phototrophic organisms on building materials. $\mathbf{a}, \mathbf{b}$ algae, mosses, and lichens on the concrete strip, wooden and brick walls
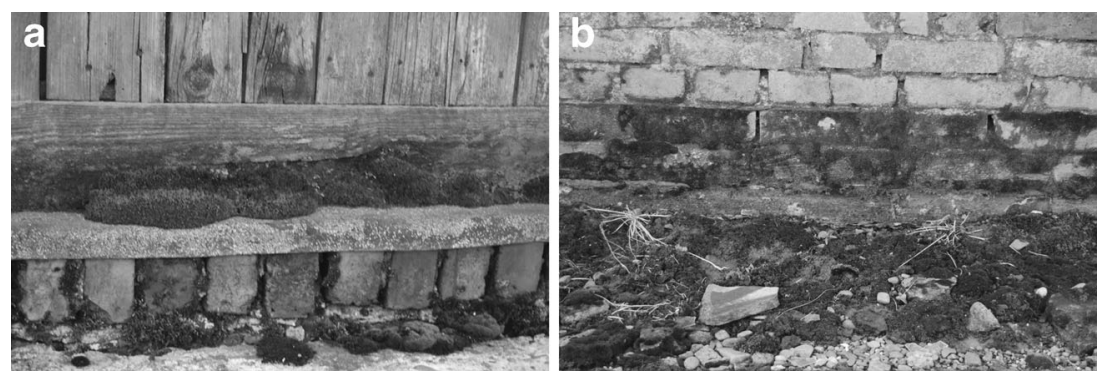
Table 2 Assessment of microbiological air contamination and surface colonization inside buildings

\begin{tabular}{|c|c|c|c|c|c|}
\hline Type of barrack & Barrack no. & $\begin{array}{l}\text { Total number of microorganisms } \\
\text { in the air }\left[\mathrm{CFU} / \mathrm{m}^{3}\right]\end{array}$ & Type of surface & & $\begin{array}{l}\text { Total number of microorganisms } \\
\text { on the surface }\left[\mathrm{CFU} / 100 \mathrm{~cm}^{2}\right]\end{array}$ \\
\hline \multirow[t]{29}{*}{ Brick barracks } & \multirow[t]{7}{*}{ B-70 } & \multirow[t]{7}{*}{$4.2 \times 10^{3} \pm 1.2 \times 10^{3}$} & \multirow[t]{4}{*}{ load-bearing wall } & $10 \mathrm{~cm}$ above floor & $1.4 \times 10^{2} \pm 2.3 \times 10^{1}$ \\
\hline & & & & $100 \mathrm{~cm}$ above floor & $3.6 \times 10^{2} \pm 3.4 \times 10^{2}$ \\
\hline & & & & $160 \mathrm{~cm}$ above floor & $5.5 \times 10^{2} \pm 2.4 \times 10^{2}$ \\
\hline & & & & $210 \mathrm{~cm}$ above floor & $2.2 \times 10^{2} \pm 2.8 \times 10^{1}$ \\
\hline & & & partition wall & & $2.9 \times 10^{2} \pm 2.2 \times 10^{2}$ \\
\hline & & & bunk bed & & $2.0 \times 10^{3} \pm 8.8 \times 10^{2}$ \\
\hline & & & door frame & & $3.7 \times 10^{1} \pm 5.2 \times 10^{1}$ \\
\hline & \multirow[t]{8}{*}{ B-113 } & \multirow[t]{8}{*}{$2.6 \times 10^{3} \pm 1.6 \times 10^{3}$} & \multirow[t]{4}{*}{ load-bearing wall } & $10 \mathrm{~cm}$ above floor & $6.5 \times 10^{2} \pm 5.8 \times 10^{2}$ \\
\hline & & & & $100 \mathrm{~cm}$ above floor & $2.1 \times 10^{1} \pm 3.0 \times 10^{1}$ \\
\hline & & & & $160 \mathrm{~cm}$ above floor & $1.2 \times 10^{1} \pm 1.7 \times 10^{1}$ \\
\hline & & & & $210 \mathrm{~cm}$ above floor & $8.0 \pm 2.5$ \\
\hline & & & bunk bed & & $2.0 \times 10^{2} \pm 1.2 \times 10^{2}$ \\
\hline & & & door frame & & $9.5 \times 10^{1} \pm 1.3 \times 10^{2}$ \\
\hline & & & floor & & $2.3 \times 10^{3} \pm 6.6 \times 10^{2}$ \\
\hline & & & ceiling & & $6.0 \times 10^{1} \pm 8.5 \times 10^{1}$ \\
\hline & \multirow[t]{7}{*}{ B-114 } & \multirow[t]{7}{*}{$1.6 \times 10^{3} \pm 4.0 \times 10^{2}$} & \multirow[t]{4}{*}{ load-bearing wall } & $10 \mathrm{~cm}$ above floor & $9.9 \times 10^{1} \pm 1.4 \times 10^{2}$ \\
\hline & & & & $100 \mathrm{~cm}$ above floor & $1.2 \times 10^{2} \pm 1.7 \times 10^{2}$ \\
\hline & & & & $160 \mathrm{~cm}$ above floor & $6.5 \times 10^{1} \pm 9.2 \times 10^{1}$ \\
\hline & & & & $210 \mathrm{~cm}$ above floor & $4.2 \times 10^{1} \pm 5.9 \times 10^{1}$ \\
\hline & & & bunk bed & & $1.5 \times 10^{2} \pm 2.1 \times 10^{2}$ \\
\hline & & & door frame & & $5.9 \times 10^{2} \pm 1.9 \times 10^{2}$ \\
\hline & & & floor & & $2.7 \times 10^{3} \pm 9.3 \times 10^{2}$ \\
\hline & \multirow[t]{7}{*}{ B-124 } & \multirow[t]{7}{*}{$3.5 \times 10^{3} \pm 2.9 \times 10^{3}$} & \multirow[t]{4}{*}{ load-bearing wall } & $10 \mathrm{~cm}$ above floor & $5.9 \times 10^{2} \pm 8.3 \times 10^{2}$ \\
\hline & & & & $100 \mathrm{~cm}$ above floor & $2.3 \times 10^{2} \pm 3.2 \times 10^{2}$ \\
\hline & & & & $160 \mathrm{~cm}$ above floor & $8.0 \pm 2.5$ \\
\hline & & & & $210 \mathrm{~cm}$ above floor & $2.7 \times 10^{1} \pm 3.7 \times 10^{1}$ \\
\hline & & & partition wall & & $1.2 \times 10^{2} \pm 1.7 \times 10^{2}$ \\
\hline & & & bunk bed & & $9.2 \pm 6.5$ \\
\hline & & & door frame & & $4.6 \times 10^{2} \pm 4.8 \times 10^{2}$ \\
\hline \multirow[t]{7}{*}{ Wooden barracks } & \multirow[t]{3}{*}{ B-159 } & \multirow[t]{3}{*}{$3.6 \times 10^{3} \pm 2.0 \times 10^{3}$} & \multirow[t]{2}{*}{ load-bearing wall } & & $5.8 \times 10^{1} \pm 8.2 \times 10^{1}$ \\
\hline & & & & & $2.2 \times 10^{1} \pm 3.1 \times 10^{1}$ \\
\hline & & & beam & & $8.7 \times 10^{2} \pm 6.8 \times 10^{2}$ \\
\hline & \multirow[t]{4}{*}{ B-169 } & \multirow[t]{4}{*}{$1.2 \times 10^{4} \pm 1.4 \times 10^{4}$} & partition wall & & $4.9 \times 10^{1} \pm 6.9 \times 10^{1}$ \\
\hline & & & beam & & $1.0 \times 10^{2} \pm 1.5 \times 10^{2}$ \\
\hline & & & bunk bed & & $1.9 \times 10^{2} \pm 1.5 \times 10^{2}$ \\
\hline & & & stove & & $1.3 \times 10^{2} \pm 9.0 \times 10^{1}$ \\
\hline
\end{tabular}

typical of these kinds of structural elements (Piotrowska and Żakowska 2010).

The total number of microorganisms per $1 \mathrm{~m}^{3}$ of air inside brick and wooden barracks ranged from $1.6 \times 10^{3}$ to $1.2 \times$ $10^{4} \mathrm{CFU}$ (Table 2). Comparative analysis of microbiological contamination of air inside the barracks versus atmospheric air (atmospheric air contamination in our study $4.2 \times 10^{3} \mathrm{CFU} /$ $\mathrm{m}^{3}$ ) shows that there are no internal sources of microbial air contamination in light of literature data (Ponce-Caballero et al. 2010).
Furthermore, we determined ATP levels on the examined surfaces inside brick and wooden barracks. The sources of ATP included microbial cells, as well as organic contaminants such as dust, cobwebs, fragments of inactive mycelium, and wood tissue. Additionally, the bioluminometric method of ATP measurement made it possible to determine viable but nonculturable (VBNC) organisms; that is, those not growing under laboratory conditions (Oliver 2005). A high level of ATP (more than 10,000 RLU) was found on surfaces close to the floor and those located from 100 to $250 \mathrm{~cm}$ above ground (Fig. 3). 
Table 3 Microorganism species predominant in the examined buildings

\begin{tabular}{|c|c|c|c|}
\hline Type of building & Surface & Organism type & Predominant species \\
\hline \multirow[t]{10}{*}{ Brick barracks } & \multirow[t]{6}{*}{ inside barracks $^{1}$} & bacteria & $\begin{array}{l}\text { Bacillus cereus, Bacillus atrophaeus, Bacillus gibsonii, Bacillus mycoides, Sporosarcina } \\
\text { aquimarina, Pseudomonas fluorescens, Micrococcus luteus, Streptomyces sp. }\end{array}$ \\
\hline & & moulds & $\begin{array}{l}\text { Acremonium sp., Cladosporium cladosporioides, Cladosporium herbarum, Alternaria } \\
\text { alternata, Humicola fuscoatra, Humicola grisea, Penicillium citreonigrum, Chaetomium } \\
\text { globosum }\end{array}$ \\
\hline & & cyanobacteria & $\begin{array}{l}\text { Scytonema drilosiphon, Chroococcus minor, Chroococcus varius, Gloeothece palea, } \\
\text { Leptolyngbya sp. }\end{array}$ \\
\hline & & algae & Diadesmis contenta, Chlorella sp. \\
\hline & & lichens & Lecanora cf. dispersa, Lecanora cf. albescens \\
\hline & & mosses & Bryum argenteum, Marchantia polymorpha, Plagiothecium curvifolium, Tortula muralis \\
\hline & \multirow[t]{4}{*}{ outside barracks ${ }^{2}$} & cyanobacteria & Leptolyngbya sp., Phormidium breve \\
\hline & & algae & Diadesmis contenta, Apatococcus lobatus \\
\hline & & lichens & $\begin{array}{l}\text { Aspicilia contorta, Candelariella aurella, Caloplaca citrina, Caloplaca decipiens, Lecanora } \\
\text { cf. albescens, Lecanora } \text { cf. dispersa, Lecidea stigmatea, Lepraria } \text { cf. incana, Physcia } \\
\text { caesia, Protoblastenia rupestris, Protoparmeliopsis muralis var. muralis, Sarcogyne } \\
\text { regularis, Verrucaria muralis, Verrucaria } \text { cf. nigrescens }\end{array}$ \\
\hline & & mosses & $\begin{array}{l}\text { Amblystegium serpens, Atrichum undulatum, Bryum argenteum, Ceratodon purpureus, } \\
\text { Climacium dendroides, Hypnum cupressiforme var. lacunosum, Marchantia polymorpha, } \\
\text { Niphotrichum canescens, Orthotrichum diaphanum, Orthotrichum anomalum, } \\
\text { Oxyrrhynchium hians, Plagiothecium curvifolium, Rhynchostegium murale, Schistidium } \\
\text { apocarpum, Tortula muralis }\end{array}$ \\
\hline \multirow[t]{9}{*}{ Wooden barracks } & \multirow[t]{6}{*}{ inside barracks ${ }^{3}$} & bacteria & $\begin{array}{l}\text { Staphylococcus equorum, Bacillus atrophaeus, Bacillus cereus, Bacillus mycoides, } \\
\text { Streptomyces sp. }\end{array}$ \\
\hline & & moulds & $\begin{array}{l}\text { Aspergillus fumigatus, Cladosporium cladosporioides, Cladosporium herbarum, Alternaria } \\
\text { alternata, Humicola fuscoatra, Penicillium citrinum }\end{array}$ \\
\hline & & cyanobacteria & Chroococcus varius, Gloeothece palea, Leptolyngbya sp. \\
\hline & & algae & Diadesmis contenta, Apatococcus lobatus, Chlorella sp. \\
\hline & & lichens & not detected \\
\hline & & mosses & not detected \\
\hline & \multirow[t]{3}{*}{ outside barracks ${ }^{4}$} & cyanobacteria & Chroococcus minor, Chroococcus varius, Gloeocapsa sp. \\
\hline & & algae & Apatococcus lobatus \\
\hline & & $\begin{array}{l}\text { lichens } \\
\text { mosses }\end{array}$ & $\begin{array}{l}\text { Lecanora conizaeoides, Lecanora symmicta, Lepraria cf. incana, Strangospora pinicola } \\
\text { not detected }\end{array}$ \\
\hline
\end{tabular}

1. Surfaces inside brick barracks: load-bearing wall, partition wall, ceiling, floor, bunk bed, door frame

2. Surfaces outside brick barracks: load-bearing wall, door, roof, strip around the building

3. Surfaces inside wooden barracks: load-bearing wall, partition wall, foundation, beam, bunk bed, stove

4. Surfaces outside wooden barracks: door, strip around the building, foundation

Algae were a major component of biological colonization of internal surfaces of wooden and brick barracks, as they are pioneers in colonizing these parts of buildings. It should be noted that in the majority of the barracks, surfaces with a high presence of algae included the floors and the bottom fragments of bathroom walls. Windows, located in the northern and north-eastern walls of these rooms, created favorable conditions for the algae development, which were additionally enhanced by increased humidity and lower temperature amplitude inside the barracks. Alga identification revealed that the interiors were dominated by blue-green algae of the genera Scytonema, Chroococcus, Gloeothece, Leptolyngbya, diatoms of the genus Diadesmis, and chlorophytes of the genera
Chlorella and Apatococcus (Table 3). The taxonomic composition of communities inside the buildings was the same, irrespective of the collection site. However, the proportions of particular taxa varied, which was reflected in the different colors and structures of the thalli and biofilms on structural elements.

Thanks to their adaptation to adverse environmental conditions (water scarcity, strong insolation), cyanobacteria and algae can colonize wooden, brick, and concrete surfaces (Barberousse et al. 2007; Samad and Adhikary 2008). Under extreme conditions, algae form monocultures with a dominating presence of one taxon that is best adjusted to the prevailing environmental factors (Kawecka and Eloranta 1994). In the 
Fig. 3 ATP levels on the examined surfaces inside wooden and brick barracks

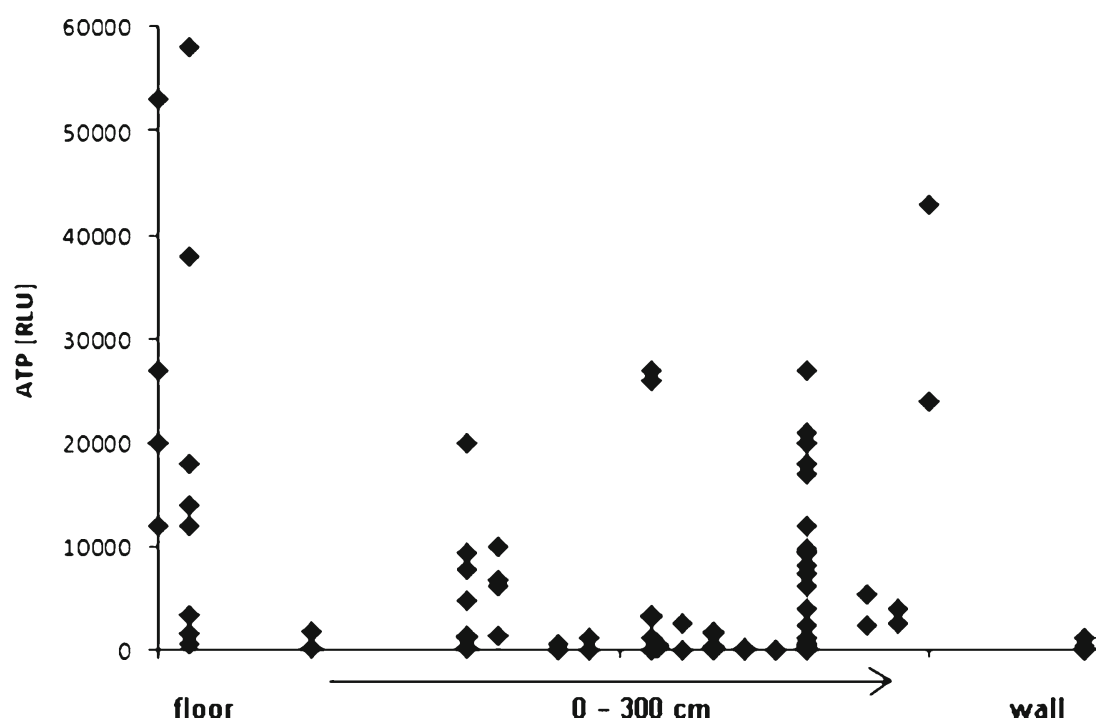

spring and summer, under high air humidity, cyanobacteria of the species Scytonema drilosiphon, known to thrive in brick buildings (Starmach 1966), proliferated on a massive scale on the brick bathroom floors.

Among the moisture-retaining thalli of cyanobacteria, the predominant diatom was Diadesmis contenta, which shows a preference for land environments. This species is characterized by considerable tolerance to varying lighting conditions (Hofmann et al. 2011), and it was found in communities not only inside, but also outside the barracks, where insolation was much more intensive. The main chlorophyte species, Apatococcus lobatus, grew with varying prevalence in algal communities on all examined surfaces. It was found to be abundant primarily in communities located on external wooden construction elements. This species is often found on construction materials such as stone, concrete, and bricks, as well as on tree trunks, in areas with low humidity and highly polluted air (Gärtner and Stoyneva 2003).

Algae were less prevalent on the external surfaces of the barracks, which were mostly colonized by lichens and mosses. Examination of brick barracks revealed lichen colonized primarily on their external walls. In terms of the vertical gradient, the greatest species diversity was observed up to the height of $1.0-1.5 \mathrm{~m}$. The presence of lichens on the external walls also depended on the exposure of the walls; they grew most abundantly on the northern and eastern walls. The species diversity of lichens was significantly higher on the external surfaces of brick barracks than wooden barracks. The dominant genera were Aspicilia, Candelariella, Caloplaca, Lecanora, Lecidea, Lepraria, Physcia, Protoblastenia, Protoparmeliopsis, Sarcogyne, and Verrucaria. The concrete strips around the buildings have a higher species diversity and coverage than the walls. Inside the buildings, only the initial thalli of Lecanora cf. dispersa and Lecanora cf. albescens were noted on window frames.
The study showed that lichens were replaced by mosses on concrete substrate. The greatest diversity of mosses was observed on the external elements of brick barracks, which is due to the variety of different substrates available to these organisms. The greatest number of species was found on the strips around the buildings, with the composition of the bryoflora dependent on the material of the strips. Niphotrichum canescens, Schistidium apocarpum, and Ceratodon purpureus were the predominant species on concrete strips (Table 3), while typical ground species (Marchantia polymorpha, Climacium dendroides, and Bryum argenteum ) were the most abundant on strips without a concrete layer. On the bricks and mortar of external wall surfaces, mosses were usually observed up to about $50 \mathrm{~cm}$ above ground, with the most widespread species being Bryum argenteum, Rhynchostegium murale, and Tortula muralis. Only four taxa were found inside brick barracks (Bryum argenteum, Marchantia polymorpha, Tortula muralis, Plagiothecium curvifolium); they grew on the walls and floor in the proximity of the windows and doors.

Interestingly, no mosses were found on the external or internal surfaces of wooden barracks. Also, the prevalence and species diversity of lichens were much lower in wooden buildings than in brick ones. Lichens were not found inside wooden barracks, while their external surfaces were colonized by Lecanora conizaeoides, Lepraria cf. incana, Lecanora symmicta, and Strangospora pinicola. The examined barracks were colonized by species that are widespread in Poland, with a wide ecological scale (Faltynowicz 2003). Lichens degrade the substrate, causing chemical erosion and mechanical fragmentation (Purvis et al. 1992). Brick buildings were mostly colonized by basophilous and calciphilous species. Organisms colonizing building substrates use them as a substitute for natural ones (Bielczyk 2006). The composition of the morphological forms of thalli and, partially, the species composition of the lichens growing on bricks and concrete in brick barracks showed that lichen 
colonization there was in its optimum stage (Lipnicki 1998). Among the lichens growing on the external surfaces of wooden barracks, except for Strangospora pinicola, there were no species exclusively connected to wood, but some of them (Lecanora conizaeoides, Lepraria cf. incana) typically occur on tree bark (Chlebicki et al. 1996). In this case, the composition of morphological forms of thalli growing on wood showed that lichen colonization was in its initial stage (Lipnicki 1998).

The species composition of the moss layer depends on the environmental conditions (type of substrate, insolation, humidity), as well as on the environmental preferences of particular species. The identified mosses included ubiquitous species (Bryum argenteum, Ceratodon purpureus, Marchantia polymorpha) (Dierßen 2001), which are widespread in Poland and are found in many habitats and on a variety of substrates (Klama 2002; Stebel 2006). Inside the examined buildings, mosses practically did not occur, while the few species recorded on the inner surfaces of brick barracks were found in the proximity of windows and doors, where they could gain access to sufficient light. In turn, the great diversity of mosses outside the brick buildings was caused by the wealth of substrates in the examined area (Klama 2002; Stebel 2006).

All the identified groups of organisms are biotic factors posing high risk of degradation to wood and mineral materials, especially in buildings exposed to the action of atmospheric conditions and capillary rise of groundwater. Despite the absence of visual symptoms of microbial development in the examined barracks, the high enzymatic and acidogenic capabilities of the predominant microflora may lead to progressive biological corrosion. The presence of algae, lichens, and mosses is undesirable, as they may metabolize the organic substances contained in the construction materials, leading to physical and chemical changes in the substrate and weakening its structure. The results of our comprehensive study reveal a vast species biodiversity among the organisms colonizing historic buildings. The isolated organisms will be used for developing biocidal preparations to limit their growth on buildings, and for creating a program for the prevention of natural biodeterioration processes in the Auschwitz II-Birkenau State Museum.

Acknowledgments The study was conducted as part of the Global Plan of Conservation and Preservation of the Auschwitz-Birkenau Memorial Site.

Open Access This article is distributed under the terms of the Creative Commons Attribution License which permits any use, distribution, and reproduction in any medium, provided the original author(s) and the source are credited.

\section{References}

Arenz EB, Held WB, Jurgens JA, Farrell RL, Blanchette RA (2006) Fungal diversity in soils and historic wood from the Ross Sea region of Antarctica. Soil Biol Biochem 38:3057-3064
Barberousse H, Rout B, Yéprémian C, Boulon G (2007) An assessment of facades coatings against colonization by aerial algae and cyanobacteria. Build Environ 42:2555-2561

Bielczyk U (2006) Distribution of calciphilous lichens in Poland. In: Lackovičová A, Guttová A, Lisiecká E, Lizoň P (eds) Central European lichens - diversity and threat. Mycotaxon Ltd, Ithaca, pp 153-164

Chlebicki A, Żarnowiec J, Cieśliński S, Klama H, Bujakiewicz A, Załuski T (1996) Epixylites, lignicolous fungi and their links with different kinds of wood. In: Faliński JB, Mułenko W (eds) Cryptogamous plants in the forest communities of Białowieża National Park. Functional groups analysis and general synthesis (Project CRYPTO 3). Phytocoenosis 8 (N.S.), Arch Geobotan 6:75-110

Clausen CA (1996) Bacterial associations with decaying wood: a review. Int Biodeterior Biodegrad 37:101-107

Crispin CA, Gaylarde CC (2005) Cyanobacteria and biodeterioration of cultural heritage: a review. Microb Ecol 49:1-9

Cwalina B (2008) Biodeterioration of concrete. ACEE 4:133-140

Cwalina B, Dzierżewicz Z (2007) Factors contributing to biological corrosion of reinforced concrete structures. Przegl Bud 7:52-59, Polish

de Boer W, Folman LB, Summerbell RC, Boddy L (2005) Living in a fungal world: impact of fungi on soil bacterial niche development. FEMS Microbiol Rev 29:795-811

Diederich P, Ertz D, Stapper N, Sérusiaux E, Van den Broeck D, Van den Boom P, Ries C (2010) Lichens of Belgium, Luxembourg and northern France. http://www.lichenology.info. Accessed 9 Sep 2012

Dierßen K (2001) Distribution, ecological amplitude and phytosociological characterization of European bryophytes. Bryophyt Bibl 56:1289

Domsch KH, Gams W, Anderson TH (1993) Compedium of soil fungi. IHW Verlag, Eching

Fattynowicz W (2003) The lichens, lichenicolous and allied fungi of Poland - an annotated checklist. Szafer Institute of Botany, Polish Academy of Sciences, Cracow

Gärtner G, Stoyneva MP (2003) First study of aerophytic cryptogams on monuments in Bulgaria. Ber nat-med Verein Innsbruck 90:73-82

Gaylarde CC, Morton LHG (1999) Deteriogenic biofilms on buildings and their control: a review. Biofouling 14:59-74

Gaylarde C, Ribas Silva M, Warscheid T (2003) Microbial impact on building materials: an overview. Mater Struct 36:342-352

Gutarowska B, Czyżowska A (2009) The ability of filamentous fungi to produce acids on indoor building materials. Ann Microbiol 59:807-813

Herrera LK, Arroyave C, Guiamet P, de Saravia SG, Videla H (2004) Biodeterioration of peridotite and other constructional materials in a building of the Colombian cultural heritage. Int Biodeterior Biodegrad 54:135-141

Hofmann G, Werum M, Lange-Bertalot H (2011) Diatomeen im süßwasser-benthos von Mitteleuropa. A.R.G. Gantner Verlag K.G, Rugell

Kawecka B, Eloranta P (1994) Introduction to ecology of algae from freshwater and terrestrial environments. Polish Scientific Publishers PWN, Warsaw

Klama H (2002) Distribution patterns of liverworts (Marchantiopsida) in natural forest communities (Białowieża Primeval Forest, NE Poland). University of Bielsko-Biala, Bielsko-Biala

Komárek J, Anagnostidis K (1999) Cyanoprokaryota: Chroococcales. In: Pascher A (ed) Süßwasserflora von Mitteleuropa. Gustaw Fischer, Jena, pp 1-548

Komárek J, Anagnostidis K (2007) Cyanoprokaryota: Oscillatoriales. In: Pascher A (ed) Süßwasser von Mitteleuropa. Elsevier GmbH, München, pp 1-758

Krzewicka B (2012) A revision of Verrucaria s.1. (Verrucariaceae) in Poland. Pol Botan Stud 27:3-143

Kukwa M (2006) The lichen genus Lepraria in Poland. Lichenol 38:293-305 
Leźnicka S (1991) The role of microorganisms in the destruction of stone monuments. Post Mikrobiol 30:375-391, Polish

Lipnicki L (1998) Formation of lichen flora on pioneer substrates (erratic blocks, the aspen bark and straw thatches). Monogr Bot 84:115-150

Nowak J (1993) Physciaceae. Lichens (Lichenes). In: Kochman J, Nowak J, Siemińska J, Skirgiełło A (ed) Flora of Poland. Spore producing plants of Poland and neighboring lands. Szafer Institute of Botany, Polish Academy of Sciences, Cracow, Poland (Polish)

Nowak J, Tobolewski Z (1975) Lichenes of Poland. Polish Scientific Publishers PWN, Cracow

Ochyra R, Żarnowiec J, Bednarek-Ochyra H (2003) Census catalogue of Polish mosses. Polish Academy of Sciences, Institute of Botany, Cracow

Oliver JD (2005) The viable but nonculturable state in bacteria. J Microbiol 43:93-100

Palmer RJ, Siebert J, Hirsch P (1991) Biomass and organic acids in sandstone of a weathering building: production by bacterial and fungal isolates. Microb Ecol 21:253-266

Papida S, Murphy W, May E (2000) Enhancement of physical; weathering of building stones by microbial populations. Int Biodeterior Biodegrad 46:305-317

Pietikäinen J, Pettersson M, Bááth E (2005) Comparison of temperature effects on soil respiration and bacterial and fungal growth rates. FEMS Microbiol Ecol 52:49-58

Piotrowska M, Żakowska Z (2010) Microbiological analysis as an essential element of mycological- building expertise. In: Karyś J (ed) Protecting buildings against dampness and biological corrosion. Polish Association of Building Mycologists, Breslau, Poland T. VII, pp 133-140 (Polish)

Ponce-Caballero C, Cerón-Palma IM, López-Pacheco M, Gamboa-Marrufo M, Quintal-Franco C (2010) Indoor-outdoor fungal-aerosols ratios of domestic homes in Merida, Mexico. Ingeniería 14-3:169-175

Pournou A, Bogomolova E (2009) Fungal colonization on excavated prehistoric wood: implications for in-situ display. Int Biodeterior Biodegrad 63:371-378

Purvis OW, Coppins BJ, Hawksworth DL, James PW, Moore DM (1992) The lichen flora of Great Britain and Ireland. The Natural History Museum on behalf of The British Lichen Society, London

Rodriguez-Navarro C, Jimenez-Lopez C, Rodriguez-Navarro A, GonzalezMunoz MT, Rodriguez-Gallego M (2007) Bacterially mediated mineralization of vaterite. Geochim Cosmochim Acta 71:1197-1213

Samad LK, Adhikary SP (2008) Diversity of micro-algae and cyanobacteria on building facades and monuments in India. Algae 23:91-114
Samson RA, Hoekstra ES, Frisvad JC, Filtenborg O (2000) Introduction to food- and airborne fungi. CBS, Delft

Santesson R, Moberg R, Nordin A, Tønsberg T, Vitikainen O (2004) Lichen-forming and lichenicolous fungi of Fennoscandia. Museum of Evolution, Uppsala University, Uppsala

Śliwa L (2007) A revision of the Lecanora dispersa complex in North America. Pol Bot J 52:1-70

Starmach K (1966) Cyanophyta, Glaucophyta. In: Starmach K (ed) Freshwater flora of Poland. Polish Scientific Publishers PWN, Warsaw

Stebel A (2006) The mosses of the Beskidy Zachodnie as a paradigm of biological and environmental changes in the flora of the Polish Western Carpatians. Habilitation thesis, No. 17/2006, Sorus, Medical University of Silesia, Silesia, Poland

Świebocka T, Pinderska-Lech J, Mensfelt J (2010) Auschwitz-Birkenau. The past and the present. http://pl.auschwitz.org/m/index.php? option $=$ com_docman\&task $=$ doc_details $\&$ gid $=481 \&$ Itemid $=82$. Accessed 10 May 2013

Szczotko M, Krogulski A (2010) The average intracellular ATP content in various microorganisms has been quantified and ATP has been shown to be a reliable biomarker of the presence of living organisms. Pol J Microbiol 59:289-294

Szweykowski J (2006) Systematic catalogue of Polish liverwort and hornwort taxa. In: Szweykowski J (ed) An annotated checklist of Polish Liverworts and Hornworts. Szafer Institute of Botany, Polish Academy of Sciences, Cracow, pp 83-100

Warscheid T, Braams J (2000) Biodeterioration of stone: a review. Int Biodeterior Biodegrad 46:343-368

Ważny J (2001) Microorganisms developing in buildings. In: Ważny J, Karyś J (eds) Protecting buildings against biological corrosion. Arkady, Warsaw, pp 52-90

Wirth V (1995a) Flechten flora. Bestimmung und Ökologische Kennzeichung der Flechten Südwestdeutschlands und angrezender Gebiete. Verlag Eugen Ulmer, Stuttgart

Wirth V (1995b) Die Flechten Baden-Württem bergs. Verlag Eugen Ulmer, Stuttgart

Wołowski K, Hindák F (2005) Atlas of Euglenophytes. VEDA, Bratislava

Zammit G, Sanchez-Moral S, Albertano P (2011) Bacterially mediated mineralization processes lead to biodeterioration of artworks in Maltese catacombs. Sci Total Environ 409:27732782 